\title{
KONTRIBUSI SUPERVISI KLINIS KEPALA SEKOLAH, MOTIVASI KERJA, IKLIM KERJA DAN TUNJANGAN PROFESI TERHADAP KEPUASAN KERJA GURU TK DI KECAMATAN KUTA UTARA
}

\author{
Ni Komang Theda Febrina Subagia, Made Yudana, Dewa Gede Hendra Divayana \\ Jurusan Administrasi Pendidikan \\ Universitas Pendidikan Ganesha \\ Singaraja, Indonesia

\begin{abstract}
e-mail: thedafebrina@gmail.com,yudana made08@yahoo.com, doktordivayana@gmail
\end{abstract}

\begin{abstract}
Abstrak
Penelitian ini bertujuan untuk mengetahui kontribusi supervisi klinis kepala sekolah, motivasi kerja, iklim kerja, dan tunjangan profesi terhadap kepuasan kerja guru TK di Kecamatan Kuta Utara secara terpisah maupun simultan. Populasi penelitian berjumlah 64 orang guru. Penelitian menggunakan rancangan ex-post facto, data dikumpulkan dengan kuesioner. Data hasil penelitian dianalisis dengan teknik regresi. Hasil penelitian menunjukkan: (1) terdapat kontribusi yang negatif tidak signifikan supervisi klinis kepala sekolah terhadap kepuasan kerja guru TK di Kecamatan Kuta Utara, nilai kontribusi sebesar -0,508 secara parsial menghasilkan -1,532 dengan sumbangan efektif sebesar $-12,86 \%$ (2) terdapat kontribusi yang positif signifikan motivasi kerja terhadap kepuasan kerja guru TK di Kecamatan Kuta Utara, nilai kontribusi sebesar 1,020 secara parsial menghasilkan 3,279 dengan sumbangan efektif sebesar $49,73 \%$ (3) terdapat kontribusi yang positif signifikan iklim kerja terhadap kepuasan kerja guru TK di Kecamatan Kuta Utara, nilai kontribusi sebesar 1,158 secara parsial menghasilkan 4,965 dengan sumbangan efektif sebesar $67,54 \%$ (4) terdapat kontribusi yang negatif signifikan tunjangan profesi terhadap kepuasan kerja guru TK di Kecamatan Kuta Utara, nilai kontribusi sebesar -1,114 secara parsial menghasilkan 2,529 dengan sumbangan efektif sebesar $-17,45 \%$ dan (5) terdapat kontribusi yang positif signifikan secara simultan supervisi klinis kepala sekolah, motivasi kerja, iklim kerja, dan tunjangan profesi terhadap kepuasan kerja guru TK di Kecamatan Kuta Utara dengan nilai kontribusi sebesar 48,428 dan sumbangan efektif sebesar $87 \%$
\end{abstract}

Kata kunci : supervisi klinis kepala sekolah, motivasi kerja, iklim kerja, tunjangan profesi, kepuasan kerja guru

\begin{abstract}
This study aims to determine the contribution of principal clinical supervision, work motivation, work climate, and profession aid toward kindergarten teacher's work satisfaction in Kuta Utara Subdistrict separately and simultaneous. The reseacrh population was 64 teachers. The research used an ex-post facto design, data was collected by questionnaire. Data were analyzed by regression techniques. The results showed: (1) there is unsignificant negative contribution of principal clinical supervision toward kindergaren teacher's work satisfaction in North Kuta Sub-district, the contribution value is $-0,508$ partially resulted in $-1,532$ with an effective contribution in $-12,86 \%$ (2) there is a significant positive contribution work motivation toward kindergarten teacher's work satisfaction in North Kuta Sub-district, the contribution value is 1,020 partially resulted in 3.279 with an effective contribution in $49,73 \%$ (3) there is a significant positive contribution the work climate toward kindergarten teacher's work satisfaction in Kuta Utara Sub-district, the value of contribution is 1,158 partially resulted in 4,965 with an effective contribution in $67,54 \%$ (4) there is a significant negative contribution profession aid toward kindergarten teacher work's satisfaction in North Kuta Sub-district, the contribution value is $-1,114$ partially resulted in 2,529 with an effective contribution in $-17,45 \%$ and (5) there are significant positive simultaneous contributions of principal clinical, work motivation, work climate, and profession aid toward kindergarten teacher work satisfaction in North Kuta Sub-district the contribution value is 48,428 and an effective contribution is $87 \%$
\end{abstract}

Keywords : Contribution Of Principal Clinical Supervision, Work Motivation, Work Climate, Profession Aid, Kindergarten Teachers' Work Satisfaction 


\section{PENDAHULUAN}

Guru merupakan ujung tombak dalam setiap jalannya pelaksanaan pendidikan di sekolah. Hal ini didasarkan pada hakikat bahwa seorang gurulah yang memiliki peran utama untuk menggerakkan kegiatan belajar mengajar di sekolah serta untuk menciptakan peserta didik yang beriman dan bertakwa kepada Tuhan Yang Maha Esa, berakhlak mulia, sehat, berilmu, cakap, kreatif, mandiri, dan menjadi warga negara yang demokratis serta bertanggung jawab sesuai dengan amanat dari tujuan pendidikan nasional yang tertuang dalam Undang Undang SISDIKNAS. Untuk mencapai tujuan pendidikan tersebut maka kepuasan kerja guru menjadi hal yang sangat penting untuk diperhatikan. Hal ini berkaitan dengan asumsi bahwa apabila para guru telah merasa puas pada dunia kerjanya yang memiliki peran sebagai tenaga pendidik di sekolah tentu harapan dari tujuan pendidikan akan dapat terlaksana, begitu sebaliknya apabila para guru tidak merasakan kepuasan kerja maka apa yang menjadi cita-cita dan amanat dari pendidikan nasional akan sangat sulit untuk diwujudkan.

Untuk mewujudkan tujuan pendidikan tersebut, akan lebih efektif apabila proses pendidikan diberikan sejak usia dini. Anak usia dini adalah anak dengan rentang umur 0-6 tahun. Masa ini adalah masa keemasan (golden age) seorang manusia, dalam masa ini manusia akan lebih cepat menerima dengan baik ilmu yang diberikan. Jika masa keemasan (golden age) ini dimanfaatkan dengan baik, diisi dengan pengetahuan dan penanaman moral yang baik maka akan lebih mudah kedepannya untuk membentuk karakter yang baik yang akan melekat pada dirinya seumur hidup. Untuk mewujudkan pendidikan di usia dini ini khususnya usia 4-6 tahun, dibutuhkan seorang yang profesional yaitu guru TK (Taman Kanak Kanak) untuk dapat mengemas pendidikan dan pembelajaran dengan model yang menyenangkan dan mudah diterima oleh anak usia dini. Terkait profesi guru TK ini di atur dalam Undang Undang No 14 Tahun 2005 tentang Guru dan Dosen secara khusus pada Pasal 1 ayat 1 .

Guru TK dalam menjalankan tugas dan kewajibannya dalam mendidik anak usia dini pada rentang usia 4-6 tahun tidaklah mudah, tentu dibutuhkan kematangan emosional untuk dapat menguasai diri disamping kemampuan intelektualnya sehingga proses pemberian ilmu pengetahuan, terlebih penanaman moral dan nilai-nilai kehidupan untuk membentuk karakter anak seperti yang diharapkan bersama dapat tersampaikan kepada peserta didik sehingga peserta didik siap melanjutkan kejenjang pendidikan yang lebih tinggi.

Menyadari pentingnya peran Guru TK dalam membentuk manusia yang cerdas ilmu dan akhlak, berkarakter dan berbudi pekerti maka sudah seharusnya guru TK mendapat perhatian yang lebih dalam lingkungan kerjanya. Pemerintah dan lembaga yang menaunginya harus mampu memberikan perasaan bahagia dan mengupayakan kepuasan kerja guru-guru TK. Hal itu dapat dilakukan dengan memberikan fasilitas dan jaminan bagi guru TK.

Namun di lapangan sering dijumpai bahwa fasilitas yang didapat oleh para guru untuk menjalankan tugas pekerjaannya masih dikatakan kurang memadai, baik dari segi sarana prasarana, suasana kerja, fasilitas finansial terkait upah atau gaji yang diterima, maupun pengawasan terhadap kinerjanya yang tujuannya untuk meningkatkan kompetensi mereka menjadi seorang pendidik.

Dalam menjalankan tugas pekerjaannya para guru perlu mendapatkan upaya controling dari atasan dalam hal ini Kepala Sekolah, selain hal ini sebagai bentuk pelaksanaan salah satu kegiatan manajemen namun juga sebagai upaya untuk penjaminan mutu atau kualitas pelaksanaan pendidikan sehari-hari yang pada akhirnya bermuara pada kualitas lulusan. Untuk mencapai tujuan ini, maka dilakukanlah sebuah upaya supervisi klinis yang dilakukan oleh Kepala Sekolah terhadap guru yang ada dibawah pimpinannya. Namun pelaksanaan kegiatan ini seakan-akan menjadi momok bagi para guru. Sebagian guru merasa kegiatan ini merupakan hal yang membebani, karena sebagian guru beranggapan bahwa Kepala Sekolah berusaha untuk mencari-cari kesalahan melalui serangkaian pengamatan dan penilaian yang dilakukan. Sehingga dalam hal ini nampak ketidaksiapan para guru dalam menghadapi pelaksanaan supervisi dan kurangnya pemahaman yang mendalam terkait pentingnya tujuan dari pelaksanaan supervisi klinis ini. 
Di dalam menjalankan perannya sebagai guru dengan rutinitas yang beragam dengan waktu kerja yang cukup panjang tak pelak membuat para guru mengalami kemunduran semangat atau motivasi dalam bekerja. Beban kerja yang begitu besar, tuntutan kerja yang harus selalu dipenuhi sebagai bentuk kewajiban dan tanggungjawab, dibarengi dengan persoalan pribadi lainnya mampu membuat para guru merasakan kejenuhan dalam bekerja. Disisi lain lingkungan kerja yang kurang mendukung yakni terkait dengan situasi dan suasana kerja yang terangkum dalam iklim kerja dalam melaksanakan kegiatan dan tugasnya akan dapat turut mempengaruhi kepuasan kerja para guru. Iklim kerja yang dimaksud adalah iklim sekolah, karena para guru melaksanakan serangkaian rutinitas pekerjaannya di lingkungan sekolah. Iklim kerja di sekolah merupakan perpaduan iklim sosial yang menyangkut tentang suasana sekolah baik itu menyangkut perihal bagaimana kepemimpinan di sekolah maupun hubungan sosial dan komunikasi yang terjadi di lingkungan sekolah yang ditunjang dengan kelengkapan sarana prasarana yang tentu dapat menjadi indikator yang mempengaruhi kepuasan terhadap iklim kerja ini. Pimpinan sekolah dalam menjalankan organisasi sekolah wajib untuk memerhatikan iklim sekolah untuk mencapai tujuan sekolah yang tentunya banyak dipengaruhi oleh lingkungan sekolah baik itu lingkungan sosial maupun fisik.

Hal berikutnya yang menjadi permasalahan adalah terkait dengan upah atau gaji yang diperoleh para guru. Membahas tentang upah merupakan permasalahan yang sangat sensitif namun hal ini sangat penting karena pada dasarnya setiap orang bekerja untuk mendapatkan upah untuk memenuhi kebutuhan hidupnya. Selain gaji yang diterima setiap bulan, untuk lebih mensejahterakan para guru maka pemerintah mencetuskan program tunjangan profesi. Namun di lapangan, berdasarkan data yang diperoleh dari IGTKI (Ikatan Guru Taman Kanak Kanak Indonesia) Kecamatan Kuta Utara sebanyak hanya 64 orang guru TK di Kecamatan Kuta Utara yang terdiri dari 14 orang PNS dan 50 orang Non PNS dari total jumlah guru sebanyak 275 orang dari total 23 sekolah telah mendapatkan tunjangan profesi yang dibayarkan setiap 3 bulan (triwulan) sekali. Sehingga secara persentase guru TK yang menerima tunjangan profesi di Kecamatan Kuta Utara sebesar $23 \%$.

Berdasarkan hal ini penulis ingin mengangkat permasalahan yang ditemukan sebagai penelitian dalam tesis ini. Karena apabila hal ini terus menerus berlangsung maka akan berimbas pada banyak hal yang dapat mempengaruhi kepuasan guru dalam melaksanakan tugasnya di sekolah tersebut.

Dengan melihat fenomena yang terjadi maka dinilai perlu untuk lebih memperhatikan kesejahteraan dan kepuasan kerja guru dari berbagai segi dan aspek. Apabila guru sebagai tenaga pendidik telah merasakan kepuasan kerja yang baik, maka tentu saja akan mempengaruhi kinerja mereka pada lembaga masing-masing, sehingga tujuan pendidikan sesuai yang dituangan dalam Undang Undang maupun visi, misi dan tujuan lembaga atau sekolahnya sebagai kekhususan dari Undang Undang dapat tercapai.

Berdasarkan latarbelakang tersebut di atas maka dalam penelitian ini dilakukan pembatasan masalah yaitu terkait dengan supervisi klinis kepala sekolah, motivasi kerja, iklim kerja, tunjangan profesi sebagai variabel bebas dan kepuasan kerja guru sebagai variabel terikat. Sehingga dengan mengetahui latar belakang dan masalah yang ditemukan di lapangan maka penelitian ini bertujuan : (1) Untuk mengetahui kontribusi yang signifikan supervisi klinis kepala sekolah terhadap kepuasan kerja guru TK di Kecamatan Kuta Utara. (2) Untuk mengetahui kontribusi yang signifikan motivasi kerja terhadap kepuasan kerja guru TK di Kecamatan Kuta Utara. (3) Untuk mengetahui kontribusi yang signifikan iklim kerja terhadap kepuasan kerja guru TK di Kecamatan Kuta Utara. (4) Untuk mengetahui kontribusi yang signifikan tunjangan profesi terhadap kepuasan kerja guru TK di Kecamatan Kuta Utara. (5) Untuk mengetahui secara bersama-sama kontribusi yang signifikan supervisi klinis kepala sekolah, motivasi kerja, iklim kerja dan tunjangan profesi terhadap kepuasan kerja guru TK di Kecamatan Kuta Utara.

Peran guru sebagai tenaga pendidik tentu memiliki banyak tantangan dalam berbagai hal. Terlebih secara khusus bagi guru yang berkecimpung mendidik anak pada tingkat anak usia dini tentu lebih merasa tertantang, karena selain para guru TK tersebut wajib untuk 
memenuhi tuntuan administrasi profesinya, menjalankan dan memenuhi tuntutan profesionalisme mereka dalam mengelola kelas dalam kaitannya dengan proses belajar mengajar, para guru TK juga diharuskan untuk dapat mengelola perasaan dan kesabaran mereka dalam mendidik anak didik. Karena sangat berbeda cara dan perlakuan mendidik anak usia dini dengan anak-anak yang berada pada tingkatan yang lebih tinggi, disinilah peran Manajemen Sumber Daya Manusia untuk memberikan perlakuan yang lebih bagi para guru, hal ini dilakukan agar para guru merasakan kepuasan kerja di dalam dunia kerjanya.

Kepuasan kerja merupakan sebuah perasaan akan adanya keinginan atau harapan yang terpenuhi dalam lingkungan kerja yang dirasakan oleh setiap orang yang berkecimpung dalam lingkungan kerja tersebut. Sinambela (2016:303) mendefiniskan bahwa kepuasan kerja adalah "perasaan seseorang terhadap pekerjaannya yang dihasilkan oleh usahanya sendiri (internal) dan yang didukung oleh hal-hal yang dari luar dirinya (eksternal), atas keadaan kerja, hasil kerja, dan kerja itu sendiri".

Menurut Gilmer dalam (Moch. As'ad,2004:114) menyatakan ada beberapa faktor yang dapat mempengaruhi kepuasan kerja antara lain: kesempatan untuk maju, keamanan kerja, gaji, manajemen kerja, kondisi kerja, pengawasan/supervisi, faktor intrinsik, komunikasi, aspek sosial, dan fasilitas.

Berdasarkan teori dari Gilmer tersebut dapat ditarik garis besar dimensi yang dapat dijadikan untuk mengukur kepuasan kerja guru adalah supervisi atau pengawasan yang dalam penelitian ini supervisi klinis kepala sekolah, motivasi kerja, iklim kerja dan upah yang dalam hal ini adalah tunjangan profesi.

Supervisi klinis merupakan sebuah bentuk bimbingan profesional yang ditujukan kepada guru yang diberikan berdasarkan atas kebutuhan melalui siklus yang sistematis yang meliputi perencanaan, observasi yang cermat atas pelaksanaan, dan pengkajian hasil observasi dengan segera dan obyektif tentang penampilan mengajarnya yang nyata.

Willem dalam Archeson dan Gall 1980 terjemahan S.L.L Sulo 1985 yang dikutip oleh (Sahertian 2008:36) mengemukakan bahwa supervisi klinis adalah "bentuk supervisi yang difokuskan pada peningkatan mengajar dengan melalui siklus yang sistematik dalam perencanaan, pengamatan, serta analisis yang insentif dan cermat tentang penampilan mengajar yang nyata serta bertujuan mengadakan perubahan dengan cara yang rasional".

Dari teori tersebut di atas dapat dilihat bahwa pelaksanaan supervisi klinis bertujuan untuk membantu para guru dalam meningkatkan kompetensi mereka sebagai tenaga pendidik, bukan untuk mencari-cari kesalahan guru, namun untuk mencari dan menemukan apa yang dibutuhkan para guru dalam menjalankan tugas kewajibannya dalam proses belajar mengajar sehari-hari. Sehingga dengan temuan tersebut apa yang dibutuhkan dapat diidentifikasikan dan dicari solusi untuk memenuhinya. Semua ini bertujuan untuk meningkatkan profesionalisme guru dan menciptakan perasaan mencintai pekerjaan sehingga para guru TK akan merasakan sebuah kepuasan kerja.

Motivasi merupakan suatu hal yang penting dimiliki oleh setiap guru dalam menjalankan tugas dan kewajibannya dalam sebuah lembaga pendidikan. Motivasi mempersoalkan apa yang menjadi alasan dan bagaimana upaya untuk mendorong suatu gairah kerja para guru agar mereka mau untuk bekerja dengan sabaik mungkin dengan memberikan semua kemampuan dan keterampilan untuk mewujudkan tujuan sekolah.

Pengertian motivasi kerja menurut Sergiovanni dalam Yudana (2011:55) adalah "keinginan (desire) dan kemauan (willingness) seseorang untuk mengambil keputusan, bertindak, dan menggunakan seluruh kemampuan psikis, sosial, dan kekuatan fisiknya dalam rangka mencapai tujuan tertentu". Terkait dengan bagaimana seseorang melakukan sesuatu untuk mencapai tujuannya ini Abraham Maslow mengemukakan teori Hierarki Kebutuhan yang dapat digunakan untuk mengukur hal tersebut dengan membagi lima kebutuhan dasar manusia antaranya: (1) kebutuhan fisiologis, (2) kebutuhan akan rasa aman, (3) kebutuhan sosial, (4) kebutuhan harga diri, (5) kebutuhan aktualisasi diri.

Sehinga berdasarkan atas teori Maslow tersebut, asumsinya apabila kelima kebutuhan dasar manusia tersebut terpenuhi maka kepuasan kerjapun akan terwujud.

Secara umum pengertian iklim kerja menururt Davis dalam Rahsel (Jurnal Manajemen Magister Informatics and Business Institute Darmajaya, 2016:110) adalah sebagai 
"lingkungan manusia yang di dalamnya para pekerja atau organisasi melakukan pekerjaan dan keberadaannya merupakan hal yang tidak dapat disentuh atau dilihat tetapi ada".

Litwin dan Mayer yang dikutip oleh Sumantri (2001) dalam Rahsel (Jurnal Manajemen Magister Informatics and Business Institute Darmajaya, membagi enam dimensi iklim kerja yaitu: (1) Flexibility Conformity, (2) Responsibility, (3) Standards, (4) Rewards, (5) Clarity dan (6) Team spirit. Sehingga ini dapat dijadikan alat untuk mengukur bagaimana keberadaan iklim kerja dalam sebuah sekolah.

Penting untuk mewujudkan iklim kerja yang kondusif di sekolah hal ini dikarenakan seorang guru menghabiskan sebagian besar waktunya beraktifias di lingkungan sekolah. Apabila guru telah merasa nyaman dan puas dengan iklim kerja di sekolahnya tentu hal tersebut akan memberikan pengaruh positif terhadap kinerjanya

Hal penting lainnya yang perlu untuk diperhatikan demi mewujudkan kepuasan kerja adalah tunjangan profesi, hal ini berkaitan dengan kesejahteraan para guru dalam hal finansial. Tunjangan profesi diatur dalam Undang Undang No 14 Tahun 2005 tentang Guru dan Dosen dan Peraturan Pemerintah No 41 Tahun 2009 tentang Tunangan Profesi Guru dan Dosen, Tunjangan Khusus Guru dan Dosen, serta Tunjangan Kehormatan Profesor.

Dalam Peraturan Pemerintah No 41 Tahun 2009 tentang Tunjangan Profesi Guru Dan Dosen, Tunjangan Khusus Guru Dan Dosen, Serta Tunjangan Kehormatan Profesor, "tunjangan profesi adalah tunjangan yang diberikan kepada guru dan dosen yang memiliki sertifikat pendidik sebagai penghargaan atas profesionalitasnya".

Latar belakang pemberian tunjangan profesi guru yaitu pasal 1 Undang-Undang Nomor 14 Tahun 2005 tentang Guru dan Dosen mengamanatkan bahwa guru mempunyai kedudukan sebagai tenaga profesional pada jenjang pendidikan anak usia dini, pendidikan dasar, dan pendidikan menengah pada jalur pendidikan formal.

Pemberian tunjangan profesi bagi guru profesional yang telah memenuhi kualifikasi tersebut terhitung sejak awal tahun anggaran berikutnya setelah guru yang bersangkutan memperoleh nomor registrasi guru dari departemen, dengan ini guru yang bersangkutan telah terdaftar secara legal sebagai tenaga pendidik professional yang diberikan sebesar 1 (satu) kali gaji pokok yang dibayarkan secara triwullan sekali kepada guru yang telah memenuhi kualifikasi sebagai penerima tunjangan profesi.

\section{METODE}

Penelitian ini bersifat expost facto atau survei, karena tidak melakukan manipulasi terhadap gejala yang diteliti dan gejalannya secara wajar telah ada di lapangan. Penelitian expost facto adalah penelitian yang menggunakan suatu pendekatan, dimana gejala (objek) yang diteliti telah ada secara wajar tanpa perlu melakukan eksperimen untuk memunculkan variabel (objek) yang ingin diteliti (Agung,2017:60).

Populasi dalam penelitian ini adalah guru TK di Kecamatan Kuta Utara yang berjumlah 64 orang dari 23 sekolah TK yang berada di lingkungan Kecamatan Kuta Utara.

Metode dari penelitian ini adalah dengan menggunakan metode explanatory survey yang bertujuan untuk menganalisis kontribusi suatu variabel bebas terhadap variabel terikatnya. Sehingga dapat diketahui : (1) hubungan pasangan skor variabel supervisi klinis kepala sekolah $\left(X_{1}\right)$ dengan kepuasan kerja guru $(Y),(2)$ hubungan pasangan skor motivasi kerja $\left(\mathrm{X}_{2}\right)$ dengan kepuasan kerja guru $(\mathrm{Y})$, (3) hubungan pasangan skor iklim kerja $\left(\mathrm{X}_{3}\right)$ dengan kepuasan kerja guru, (4) hubungan tunjangan profesi $\left(X_{4}\right)$ dengan kepuasan kerja guru (Y), (5) hubungan pasangan skor secara bersama-sama antara supervisi klinis kepala sekolah $\left(X_{1}\right)$, motivasi kerja $\left(X_{2}\right)$, iklim kerja $\left(X_{3}\right)$ dan tunjangan profesi $\left(X_{4}\right)$ dengan kepuasan kerja guru $(Y)$.

Metode pengambilan data yang digunakan dalam penelitian ini adalah desain kuantiatif menggunakan analisis statistik dengan tekhnik regresi untuk mengukur 4 variabel bebas dan 1 variabel terikat.

Adapun langkah dari proses analisis ini antara lain : (1) deskripsi data, (2) persyaratan analisis, (3) pengujian hipotesis. Hasil dari deskripsi data akan digunakan untuk menggambarkan kontribusi dari tiap-tiap variabel bebas teradap variabel terikat. Selanjutnya data yang telah diperoleh dari penelitian dideskripsikan menurut masing-masing variabel. 
Selanjutnya dicari harga rerata, standar deviasi, modus, dan median seiap variabel yang diteliti, untuk tujuan tersebut dibuat terlebih dahuku tabel distribusi frekuensi interval.

Sebelum dilakukan analisis korelasi, regresi sederhana maupun ganda, peneliti terlebih dahulu akan melakukan uji persyaratan analisis yaitu uji normalitas sebaran data, uji linieritas dan keberatian arah regresi, uji multikolinieritas, uji heteroskedastisitas, dana uji autokorelasi.

Untuk menguji hipotesis pertama, kedua, ketiga dan keempat digunakan analisis regresi sederhana sedangkan untuk menguji hipotesis kelima digunakan teknik analisis regresi berganda kemudian dilanjutkan dengan uji determinan yang mana seluruh kegiatan analisis dalam penelitian ni dibantu dengan menggunakan SPSS 22.00 for windows.

\section{HASIL DAN PEMBAHASAN}

Berdasarkan atas pengolahan data yang telah dilakukan, maka dapat dikemukakan sebagai berikut:

(1) Berdasarkan pengujian atas data penelitian kontribusi variabel supervisi klinis kepala sekolah terhadap kepuasan kerja guru TK di Kecamatan Kuta Utara, hipotesis pertama dalam penelitian ini diperoleh bahwa terdapat kontribusi yang negatif tidak signifikan supervisi klinis kepala sekolah terhadap kepuasan kerja Guru TK di Kecamatan Kuta Utara. Hal ini dikarenakan berdasarkan hasil penelitian pada table Coefficients menunjukkan bahwa kontribusi supervisi klinis kepala sekolah $\left(\mathrm{X}_{1}\right)$ terhadap kepuasan kerja guru (Y) menghasilkan nilai koefisien variabel bernilai negatif sebesar $-0,508$ maka artinya apabila nilai supervisi klinis kepala sekolah $\left(X_{1}\right)$ naik satu satuan maka kepuasan kerja guru $(Y)$ akan turun sebesar 0,508 dan setelah diuji secara parsial dengan menggunakan uji $\mathrm{T}$, diperoleh nilai T hitung sebesar -1,532 lebih kecil dari nilai T tabel sebesar 2,045 dengan Sumbangan Efektif sebesar $-12,8 \%$. Maka dapat disimpulkan bahwa supervisi klinis kepala sekolah $\left(\mathrm{X}_{1}\right)$ memiliki kontribusi negatif tidak signifikan terhadap kepuasan kerja guru (Y).

Pada penelitian ini indikator yang memiliki nilai terendah adalah terkait dengan waktu pelaksanaan dan teknik pelaksanaan supervisi klinis yang digunakan. Hal ini sejalan dengan pandangan sebagian besar para guru di lapangan bahwa masih mengganggap supervisi klinis tersebut masih menjadi sesuatu hal yang membebani. Guru merasa tidak leluasa tampil mengajar di dalam kelas seperti biasanya karena mereka merasa sedang diawasi dan dinilai oleh kepala sekolah, sehingga akan mempengaruhi cara mengajarnya pada saat itu, karena stigma ini telah tertanam dalam diri mereka maka waktu pelaksanaan supervisi klinis ini akan dirasakan lama oleh para guru. Frekuensi pelaksanaan supervisi klinis di lapangan juga perlu untuk menjadi perhatian, frekuensi pelaksanaan yang tidak selalu teratur menjadikan kegiatan supervisi klinis ini dirasa kurang bersahabat bagi sebagian guru, sehingga apabila diadakan supervisi klinis guru sudah lebih dulu merasa terbebani dan menganggap supervisi sebagai sesuatu hal yang menegangkan. Apabila pelaksanaan supervisi klinis ini dilakukan secara teratur, maka guru akan merasa terbiasa untuk menghadapinya dan anggapan bahwa supervisi klinis sebagai sesuatu hal yang membebani akan dapat berkurang. Disamping waktu dan frekuensi pelaskanaan supervisi klinis, berdasarkan hasil penelitian, teknik pelaksanaan supervisi klinis juga menyumbangkan nilai yang kecil pada hasil penelitian supervisi klinis kepala sekolah. Hal ini berarti bahwa sebagian guru merasa kurang sesuai dengan teknik atau gaya supervisi klinis yang dilakukan terhadapnya, oleh karenanya kepala sekolah sebagai supervisor perlu untuk memahami karakter setiap guru untuk dapat mengambil tindakan teknik supervisi yang mana yang sesuai digunakan bagi setiap guru, sehingga maksud dan tujuan pelaksanaan supervisi dapat diterima dengan baik dan penuh kesadaran oleh setiap guru.

Berdasarkan pemaparan di atas maka disimpulkan bahwa supervisi klinis kepala sekolah memiliki kontribusi yang negatif tidak signifikan terhadap kepuasan kerja guru TK di Kecamatan Kuta Utara.

(2) Berdasarkan pengujian atas data penelitian kontribusi variabel motivasi kerja terhadap kepuasan kerja guru TK di Kecamatan Kuta Utara, hipotesis kedua dalam penelitian ini dinyatakan bahwa terdapat kontribusi yang posititif signifikan secara parsial motivasi kerja terdahap kepuasan kerja guru TK di Kecamatan Kuta Utara. Dimana pada table Coefficients 
menunjukkan bahwa kontribusi motivasi kerja $\left(\mathrm{X}_{2}\right)$ terhadap kepuasan kerja guru (Y) menghasilkan nilai koefisien bernilai positif sebesar 1,020 maka artinya apabila nilai motivasi kerja $\left(\mathrm{X}_{2}\right)$ naik satu satuan maka kepuasan kerja guru $(\mathrm{Y})$ akan naik sebesar 1,020 dan setelah diuji secara parsial dengan menggunakan uji $\mathrm{T}$, diperoleh nilai $\mathrm{T}$ hitung sebesar 3,279 lebih besar dari nilai T table sebesar 2,045 dengan Sumbangan Efektif sebesar 49,7\%. Maka dapat disimpulkan bahwa motivasi kerja memiliki kontribusi yang positif signifikan terhadap Kepuasan Kerja guru TK di Kecamatan Kuta Utara.

Hasil penelitian ini diperkuat dengan penelitian Afia (2013) dengan judul "Pengaruh Motivasi Terhadap Kepuasan Kerja Guru Dan Karyawan Pada Unit SMP Yayasan Pendidikan Dharma Putra" dalam penelitian ini motivasi mempunyai pengaruh yang signifikan terhadap kepuasan kerja sebesar $55,4 \%$ dan sisanya sebesar $44,6 \%$ dipengaruhi oleh faktor lain yang tidak diteliti.

Berikutnya adalah penelitian Juniari (2015) dengan judul "Pengaruh Motivasi Terhadap Kepuasan Kerja Dan Kinerja Pegawai Negeri Sipil (PNS) di Sekolah Tinggi Pariwisata Nusa Dua Bali". Dimana Secara keseluruhan responden menilai cukup baik variabel motivasi, dengan nilai rata-rata 3,19. Dari 5 indikator motivasi, indikator sosial (X3) mendapat respon tertinggi dengan nilai rata-rata 3,24. Sedangkan indikator penghargaan (X4) berada di urutan terendah dengan nilai rata-rata 3,06. Dalam mengukur convergent validity, penelitian ini menggunakan batas minimal loading factor sebesar 0,50. Hasil pengolahan data menunjukkan kelima indikator dari variabel motivasi memiliki nilai outer loadings lebih dari 0,50 dan indikator sosial (X3) memiliki nilai outer loadings paling besar yaitu 0,905 sehingga menjadi ukuran terkuat dari variabel motivasi. Dapat dinyatakan bahwa kelima indikator motivasi merupakan indikator yang valid dan signifikan sebagai pengukur variabel kepuasan kerja dan kinerja.

Motivasi kerja merupakan hal yang sangat penting ada dalam diri setiap guru, karena motivasi kerja merupakan penggerak seorang guru untuk dapat melaksanakan tugas pekerjaannya. Motivasi satu orang dengan yang lain tidaklah sama, dimana motivasi kerja tersebut memang ada dan timbul dari diri pribadi seseorang, maupun dari luar berupa rangsangan dari luar dirinya dan respon dalam menerima rangsangan tersebut. Terkait dengan jenis motivasi, Priansa (2014:204) menyatakan bahwa "motivasi dapat dibagi menjadi dua yaitu pertama motivasi intrinsik yaitu motivasi yang timbul dari dalam diri sendiri, yang aktif dan berfungsi tanpa adanya rangsangan dari luar, kedua motivasi ekstrinsik yaitu motivasi yang timbul dari luar pribadi seseorang". Untuk mengetahui prilaku, upaya dan tujuan seorang guru dalam menjalankan pekerjaannya sebagai tenaga pendidik, perlu dikaji dengan teori hierarki kebutuhan Maslow yang membagi kebutuhan manusia menjadi lima yaitu: (1) kebutuhan fisiologis (2) kebutuhan atas rasa aman (3) kebutuhan sosial (4) kebutuhan harga diri (5) kebutuhan aktualisasi diri. Sehingga apabila lima kebutuhan dasar tersebut erpenuhi maka motivasi seseorang akan meningkat dan berimbas pula pada kepuasannya dalam bekerja.

Berdasarkan pemaparan di atas maka disimpulkan bahwa motivasi kerja memiliki kontribusi yang positif signifikan terhadap kepuasan kerja guru TK di Kecamatan Kuta Utara.

(3) Berdasarkan pengujian atas data penelitian kontribusi variabel iklim kerja terhadap kepuasan kerja guru TK di Kecamatan Kuta Utara, hipotesis ketiga dalam penelitian ini adalah terdapat kontribusi positif signifikan antara iklim kerja terdahap kepuasan kerja guru TK di Kecamatan Kuta Utara. Dimana table Coefficients menunjukkan bahwa kontribusi iklim kerja $\left(\mathrm{X}_{3}\right)$ terhadap kepuasan kerja guru $(\mathrm{Y})$ menghasilkan nilai koefisien variabel Iklim Kerja $\left(X_{3}\right)$ bernilai positif sebesar 1,158 maka artinya apabila nilai iklim kerja $\left(X_{3}\right)$ naik satu satuan maka kepuasan kerja guru (Y) akan naik sebesar 1,158 dan setelah diuji secara parsial dengan menggunakan uji $\mathrm{T}$, diperoleh nilai $\mathrm{T}$ hitung sebesar 4,965. Nilai $\mathrm{T}$ hitung ini lebih besar dari nilai T table sebesar 2,045. Dengan Sumbangan Efektif sebesar 67,5\%. Maka dapat disimpulkan bahwa Iklim Kerja $\left(X_{3}\right)$ memiliki kontribusi yang signifikan terhadap Kepuasan Kerja Guru (Y).

Hasil penelitian ini diperkuat dengan penelitian sebelumnya yaitu penelitian Ghufron (2016) "Kepuasan Kerja Guru PAUD Ditinjau Dari Iklim Kelas Dan Efikasi Mengajar". Hasil penelitian menunjukkan bahwa iklim sekolah mempunyai korelasi positif dan signifikan 
dengan kepuasan kerja guru sebesar 0,425, dengan koefisien determinasi sebesar 0,18. Berdasarkan hasil penelitian ini menegaskan bahwa iklim sekolah mempunyai korelasi positif dan signifikan dengan kepuasan kerja guru sebesar 0,425.

Penelitian berikutnya yaitu Diyanti,dkk (2017) dengan judul "Pengaruh Motivasi Kerja dan Iklim Kerja Terhadap Kepuasan Kerja dan Implikasinya Terhadap Kinerja Tenaga Kependidikan Institut Pertanian Bogor". Berdasarkan analisis SEM-PLS, diketahui bahwa motivasi kerja dan iklim berpengaruh nyata terhadap kepuasan kerja Tendik IPB, kepuasan kerja berpengaruh terhadap kinerja Tendik. Nilai R-Square untuk kepuasan adalah 0,458. Artinya, motivasi kerja dan iklim kerja mempunyai kontribusi positif terhadap kepuasan 45,8 $\%$ dan $54,2 \%$ dipengaruhi oleh faktor lain.

Penting untuk mewujudkan iklim kerja yang kondusif di lingkungan sekolah, hal ini sebagai upaya untuk memberikan kenyamanan bagi guru dalam menjalankan tugasnya dan beraktifitas di lingkungan sekolah, sebab semakin baik iklim kerja yang diterima dan dirasakan oleh para guru dalam lingkungan kerjanya maka kepuasan kerja yang dirasakan pun meningkat. Litwin dan Mayer membagi iklim kerja menjadi enam dimensi yaitu: (1) Flexibility Conformity (2) Responsibility (3) Standards (4) Rewards (5) Clarity dan (6) Team spirit, dengan pembagian dimensi ini kepala sekolah sebagai pemimpin sekolah bersamasama seluruh civitas di lingkungan sekolah agar dapat mewujudkan setiap dimensi iklim kerja ini dengan baik demi terwujudnya iklim kerja yang baik.

Berdasarkan pemaparan di atas disimpulkan bahwa iklim kerja memiliki kontribusi yang posiif signifikan terhadap kepuasan kerja guru TK di Kecamatan Kuta Utara.

(4) Berdasarkan pengujian atas data penelitian kontribusi tunjangan profesi terhadap kepuasan kerja guru TK di Kecamatan Kuta Utara, hipotesis keempat dalam penelitian ini adalah bahwa tunjangan profesi memiliki kontribusi negatif signifikan terhadap kepuasan kerja guru. Dimana tabel Coefficients menunjukkan bahwa kontribusi tunjangan profesi $\left(X_{4}\right)$ terhadap kepuasan kerja guru $(Y)$ menghasilkan nilai koefisien bernilai -1,144 maka artinya apabila nilai Tunjangan Profesi $\left(\mathrm{X}_{4}\right)$ naik satu satuan maka kepuasan kerja guru $(\mathrm{Y})$ akan turun sebesar 1,144 dan setelah diuji secara parsial dengan menggunakan uji $\mathrm{T}$, diperoleh nilai $\mathrm{T}$ hitung sebesar 2,529 lebih besar dari nilai $\mathrm{T}$ table sebesar 2,045 sehingga dapat disimpulkan bahwa ada kontribusi yang negatif signifikan secara parsial antara tunjangan profesi $\left(\mathrm{X}_{4}\right)$ terhadap kepuasan kerja guru $(\mathrm{Y})$, dengan nilai Sumbangan Efektif sebesar 17,4\%. Maka dapat disimpulkan bahwa Tunjangan Profesi $\left(X_{4}\right)$ memiliki kontribusi negatif signifikan terhadap Kepuasan Kerja Guru (Y).

Atas hasil hipotesis ini, dimana dikatakan bahwa tunjangan profesi memiliki kontribusi negatif signifikan yang menghasilkan nilai koefisien variabel bernilai $-1,144$ yang artinya jika nilai tunjangan profesi $\left(\mathrm{X}_{4}\right)$ naik satu satuan maka kepuasan kerja guru $(\mathrm{Y})$ akan turun sebesar 1,144 seharusnya tidak terjadi, namun di lapangan ada beberapa hal yang dapat memungkinkan hal ini dapat terjadi, karena berdasarkan hasil penelitiain yang diperoleh guru menyatakan bahwa merasa cukup berat dengan sistem dan persyaratan pengajuan tunjangan profesi ini, hal ini dapat dilihat pada hasil penelitian ini indikator yang memiliki nilai terendah adalah sistem pengajuan tunjangna profesi. selain itu dapat diperkuat juga dari data yang didapat bahwa hanya sebanyak 60 dari 275 orang, atau $23 \%$ orang guru TK di Kecamatan Utara yang telah berhasil memperoleh tunjangan profesi. Fenomena ini bisa terjadi di lapangan karena, guru merasa pengajuan untuk mendapatkan tunjangan profesi tersebut masih tergolong rumit dan memberatkan. Sebagian guru merasa proses pengajuan tergolong sulit dan rumit baik dari kelengkapan persyaratan administrasinya, tuntutan laporan-laporan yang harus diselesaikan dan dilaporkan dengan segera, sistem yang dirasa sulit sehingga guru merasa bahwa persyaratan pengajuan lebih berat daripada jumlah besaran tunjangan profesi yang diterima. Hal ini berarti bahwa kepuasan kerja guru TK di Kecamatan Kuta Utara tidak semata-mata dapat meningkat oleh besarnya jumlah tunjangan profesi yang diterima saja. Sehingga dalam hal ini ada faktor-fakor lain yang dapat mengalahkan tunjangan profesi dalam meningkatkan kepuasan kerja guru. Pada penelitian ini iklim kerja dan motivasi kerja dapat mengalahkan tunjangan profesi dalam meningkatkan kepuasan kerja guru, hal ini berarti bahwa guru TK di Kecamatan Kuta Utara lebih mengutamakan aspek lain misalnya suasana kerja yang harmonis dan penuh keakraban, 
lingkungan kerja yang mendukung, jaminan keamanan kerja, kesempatan untuk maju dan berkarir atau hal lainya dalam meningkatkan kepuasan kerjanya.

Berdasarkan pemaparan di atas maka disimpulkan bahwa tunjangan profesi memiliki kontribusi negatif signifikan terhadap kepuasan kerja guru TK di Kecaamatan Kuta Utara.

(5) Berdasarkan pengujian atas data penelitian kontribusi supervisi klinis kepala sekolah, motivasi kerja, iklim kerja dan tunjangan profesi terhadap kepuasan kerja guru TK di Kecamatan Kuta Utara, hipotesis kelima pada penelitian ini ditunjang juga dengan penelitian milik Hartawan (2017) dengan judul "Determinasi Kemampuan Manajerial Kepala Sekolah, Iklim Kerja, Motivasi Kerja Guru Terhadap Kepuasan Kerja Guru SMP Negeri 3 Bangli”. Dalam penelitian Hartawan ini, memiliki 2 variabel bebas dan 1 variabel terikat yang sama yang dipakai untuk mengukur kepuasan kerja guru, yaitu iklim kerja dan motivasi kerja. Dalam penelitian tersebut di temukan bahwa iklim kerja memiliki determinasi yang signifikan terhadap kepuasan kerja guru sebesar 0,452 dengan determinasi 39\%. Sedangkan motivasi kerja memiliki determinasi yang signifikan terhadap kepuasan kerja guru sebesar 0,565 dengan determinasi $47 \%$.

Hal ini mengindikasikan bahwa secara parsial motivasi kerja dan iklim kerja juga dapat dipakai sebagai prediktor kepuasan kerja guru TK di Kecamatan Kuta Utara karena dalam penelitian ini motivasi kerja dan iklim kerja memiliki kontribusi yang positif signifikan terhadap kepuasan kerja yang masing-masing memiliki nilai kontribusi sebesar 1,020 dan secara parsial sebesar 3,279 dengan SE sebesar 49,7\% untuk variabel motivasi kerja terhadap kepuasan kerja guru, sedangan kontribusi iklim kerja terhadap kepuasan kerja guru menghasilkan nilai kontribusi sebesar 1,158, dan secara parsial sebesar 4,965 dengan SE sebesar $67,5 \%$.

Sedangkan untuk variabel supervisi klinis kepala sekolah dan tunjangan profesi masih bernilai negatif secara parsial terhadap kepuasan kerja guru TK di Kecamatan Kuta Utara, hal ini dikarenakan penelitian dilakukan pada dimensi, waktu dan objek yang berbeda dengan penelitian-penelitan lainnya yang mengangkat tentang kontribusi supervisi klinis kepala sekolah mapupun tunjangan profesi terhadap kepuasan kerja. Sehingga fenomena ini dapat dijadikan sebagai penelitian lanjutan bagi peneliti maupun peneliti lainnya dikemudian hari.

Atas keempat variabel bebas yag telah diukur secara bersama-sama melalui Uji $F$, supervisi klinis kepala sekolah, motivasi kerja, iklim kerja dan tunjangan profesi memiliki kontribusi yang signifikan terhadap kepuasan kerja guru TK di Kecamatan Kuta Utara

Berdasarkan penelitian tersebut di atas, dapat disimpulkan bahwa terdapat kontribusi yang signifikan secara bersama-sama supervisi klinis kepala sekolah, motivasi kerja, iklim kerja, dan tunjangan profesi terhadap kepuasan kerja guru TK di Kecamatan Kuta Utara dengan Sumbangan Efektif sebesar 87\% dan nilai determinasi sebesar 85,2\%.

\section{SIMPULAN DAN SARAN}

Berdasarkan hasil penelitian dengan analisis data yang telah dilakukan yaitu Kontribusi Supervisi Klinis Kepala Sekolah, Motivasi Kerja, Iklim Kerja dan Tunjangan Profesi terhadap Kepuasan Kerja Guru TK di Kecamatan Kuta Utara, maka diperoleh simpulan sebagai berikut:

(1) Terdapat kontribusi yang negatif tidak signifikan supervisi klinis kepala sekolah terhadap kepuasan kerja guru TK di Kecamatan Kuta Utara, dimana nilai koefisien kontribusi sebesar 0,508 dam diuji secara parsial menghasilkan -1,532 dengan SE sebesar $-12,86 \%$ (2) Terdapat kontribusi yang positif signifikan motivasi kerja terhadap kepuasan kerja guru TK di Kecamatan Kuta Utara, dimana nilai koefisien kontribusi sebesar 1,020 dan diuji secara parsial menghasilkan 3,279 dengan SE sebesar 49,73\% (3) Terdapat kontribusi yang positif signifikan iklim kerja terhadap kepuasan kerja guru TK di Kecamatan Kuta Utara, dimana nilai koefisien kontribusi sebesar 1,158 dan diuji secara parsial menghasilkan 4,965 dengan SE sebesar 67,54\% (4) Terdapat kontribusi yang negatif signifikan tunjangan profesi terhadap kepuasan kerja guru TK di Kecamatan Kuta Utara, dimana nilai koefisien kontribusi sebesar -1,144, dan diuji secara parsial menghasilkan 2,529 SE sebesar -17,45\% (5) Terdapat kontribusi yang signifikan secara simultan Supervisi Klinis Kepala Sekolah, 
Motivasi Kerja, Iklim Kerja dan Tunjangan Profesi terhadap Kepuasan Kerja Guru TK di Kecamatan Kuta Utara sebesar 48,42 dan SE sebesar $87 \%$.

Berdasarkan simpulan yang telah dipaparkan di atas maka dapat disarankan beberapa hal antara lain:

(1) kepala sekolah diharapkan untuk melakukan kegiatan supervisi klinis secara lebih rutin dan memilih teknik supervisi yang sesuai dengan karakteristik guru yang disupervisi sehingga pelaksanaannya dapat diterima dengan lebih baik, maksud dan tujuan supervisi tersampaikan.

(2) guru dan kepala sekolah diharapkan untuk meningkatkan motivasi kerjanya demi menjaga kualitas diri sebagai tenaga pendidik profesional.

(3) Kepala sekolah dan para guru bekerjasama untuk mempertahankan iklim kerja yang sudah berjalan dengan baik. (4) Kepala sekolah agar lebih memotivasi dan memfasilitasi guru untuk mengajukan tunjangan profesi, sehingga persentase jumlah guru penerima tunjangan profesi meningkat

\section{DAFTAR PUSTAKA}

Agung, Anak Agung Gede. 2017. Statistika Inferensial Untuk Pendidikan (Disertai SPSS). Singaraja

As'ad, Mohamad. 2004. Psikologi Industri. Yogyakarta: Liberty

Rahsel, Yoeyong. 2016. Pengaruh Iklim Kerja Terhadap Kinerja Pegawai Adminisrasi Pusat Universiats Padjajaran Bandung. Jurnal Manajemen Magister Vol. 2 No.1

Sahertian, Piet. 2008. Konsep Dasar dan Teknik Supervisi Pendidikan. Jakarta: Rineka Cipta

Sinambela, Lijan Poltak. 2016. Manajemen Sumber Daya Manusia. Jakarta: Bumi Aksara

Winardi. 2001. Motivasi dan Pemotivasi dalam Manajemen. Jakarta: Raja Grafindo Persada

Yudana, Made. 2011. Buku Ajar Supervisi Akademik dalam Peningkatan Profesionalisme Guru. Singaraja 